\title{
MEMBANGUN KARAKTER PTK-PNF MELALUI PENINGKATAN KOMPETENSI PERSONAL DAN SOSIAL
}

\begin{abstract}
Harun AI Rasyid
Abstract

Non-formal and informal education is a part of national education that has a broad target. It has large target, geographical variation, and differences in need and demand. To reach this target, this Directorate General is supported by technical and educational staff. The staff are demanded to provide the community with high quality services. They must have personal, social, professional, and academic competences. Although all of these competences have important roles, but this article only discusses personal and social competences. Personal competence gives a strong foundation to deal with all problems, and social competence gives a foundation for human interaction. Both competences influence individual success and reflect the commitment and integrity in their duties.
\end{abstract}

Keywords: personal competence, social competence, non-formal education, educational staff.

\section{PENDAHULUAN}

Pendidik dan Tenaga Kependidikan Pendidikan Nonformal (PTK-PNF) memiliki peran strategis dalam upaya mencerdaskan kehidupan bangsa. Oleh karena itu, PTK-PNF hendaknya memiliki kompetensi khusus yang dapat mendukung pelaksanaan tugas pokoknya. Menurut Humpreys (2003), kompetensi merupakan variabel independent yang merupakan predictor bagi kinerja yang superior secara statistik menghasilkan kinerja paling tidak 1 Standar Deviasi (SD) di atas ratarata. Hal ini menunjukkan bahwa individu yang memiliki kompetensi sesuai dengan tuntutan bidang kerjanya memiliki kinerja yang lebih tinggi apabila dibandingkan dengan individu yang tidak memiliki kompetensi yang sesuai.

Penggunaan istilah kompetensi ini sebenarnya dimulai semenjak sekitar 30 tahun lalu, pada saat Mc. Clelland (1953) menuliskan Testing For Competence Rather Than Intelligence. Ide-ide ini dilanjutkan oleh Spencer and Spencer (1956) yang menyusun Hay/ McBer's Generic Competency Dictionary dengan dipopulerkannya emotional intelligence yang selanjutnya diukur dengan Emotional Quotient (EQ) sebagai indikator kesuksesan seseorang selain IQ. Kompetensi yang menunjang pelaksanaan tugas guna peningkatan profesionalisme dituntut dikuasai oleh sumber daya manusia dalam setiap aspek pekerjaan, termasuk di dalamnya PTK-PNF yang bergerak di bidang pendidikan.

\footnotetext{
* Kepala BPPNFI Regional IV
}

Dua kompetensi khusus yang harus dimiliki oleh PTK-PNF adalah kompetensi personal dan sosial yang memadai karena bidang tugasnya berhubungan erat dengan masyarakat dan berbagai pihak lain yang menuntut kearifan dan budi pekerti luhur sehingga dapat melaksanakan tugasnya dengan penuh tanggung jawab.

Kompetensi sosial merupakan gambaran integritas individu yang tercermin dalam kemampuan individu ketika mengembangkan hubungan vertikal dan horizontal yang tercermin dalam kapasitas moral dan mental seseorang sehingga tampil sebagai pribadi yang matang dan mantap. Kompetensi sosial merupakan gambaran kemampuan individu dalam berinteraksi dengan orang lain sehingga dapat memperkokoh eksistensi diri melalui fleksibilitas dan kemampuan beradaptasi dengan lingkungan.

Kompetensi personal dan sosial dapat dipelajari dan dioptimalkan sehingga memberikan pemahaman yang cukup bagi seseorang dalam mengembangkan diri dan berinteraksi dengan orang lain. Ini sama halnya dengan membangkitkan gen positif yang selama ini masih dorman (tidur). Kedua kemampuan ini kemungkinan masih tersimpan dalam gen-gen seseorang dan perlu diaktifkan melalui proses belajar secara terus menerus. Proses belajar ini akan menumbuhkan pengetahuan, pemahaman, dan penerimaan seseorang terhadap nilai serta norma yang berlaku, baik norma agama maupun kemasyarakatan sehingga dalam perjalanannya tidak sering mengalami benturan. Proses belajar ini dilakukan secara terus 
menerus sehingga akan semakin menguat. Secara khusus yang perlu dikembangkan untuk menguatkan kedua kompetensi ini adalah kemampuan berkomunikasi, kemampuan mengatasi masalah (coping mechanism), kepedulian, pemaknaaan hidup dan kehidupan secara utuh, kepedulian (caring), kemauan untuk berbagi (sharing), kasih sayang (loving), kepemilikan (ownership), perasaan (feeling), dan kebe- ranian dalam pengambilan keputusan.

Kompetensi personal dan sosial yang dimiliki PTK-PNF akan mampu mendukung pencapaian tujuan. Dengan demikian, PTK-PNF akan memiliki bekal dalam menghadapi permasalahan lapangan yang kompleks. Bekal ini akan menjadi kekuatan yang semakin lama semakin kokoh sehingga tumbuh menjadi pribadi yang memiliki kepribadian tangguh.

\section{PEMBAHASAN}

\section{Membangun Karakter}

Membangun karakter merupakan proses panjang dan tidak dapat dilakukan dalam hitungan satu atau dua tahun. Proses panjang ini berjalan terus menerus, tidak kenal henti maupun menyerah. Bagi PTK-PNF, membangun karakter merupakan tuntutan utama karena peranannya di masyarakat yang cukup strategis. PTKPNF menjadi salah satu teladan bagi masyarakat di bidang pendidikan sehingga dituntut memiliki karakter kuat yang patut untuk ditiru.

Proses panjang membangun karakter ini dapat dimulai dari diri sendiri, keluarga, dan masyarakat. Hal yang paling utama adalah dimulai dari diri sendiri kemudian diharapkan dapat ditularkan kepada sekelilingnya. Hal terpenting yang diperlukan dalam membangun karakter adalah sebagai berikut.

1. Komitmen dan konsistensi. Ini diperlukan agar PTKPNF memiliki tanggung jawab moral dan profesional terhadap masyarakat dan bidang tugasnya.

2. Pola pikir positif dan terbuka sehingga PTK-PNF menjadi pribadi unggul, tangguh, dan berwawasan luas.

3. Keuletan dan kesungguhan hati sehingga tahan terhadap segala ujian, tantangan maupun rintangan.

PTK-PNF yang memiliki karakter merupakan harapan dari masyarakat karena merupakan pribadipribadi yang memiliki integritas moral dan tanggung jawab profesional yang tinggi dalam mengawal keberhasilan program serta memberikan layanan prima bagi masyarakat. Dengan demikian, PTK-PNF yang menghadapi berbagai tantangan pada medan kerja yang cukup berat akan siap mendedikasikan hidupnya bagi kepentingan masyarakat.

\section{Kompetensi Personal bagi PTK-PNF}

Kompetensi personal merupakan kecakapan yang bersifat individual yang lebih merujuk kepada kemampuan seseorang dalam mengenali dirinya sendiri dalam arti memahami kekuatan dan kelemahannya serta peka terhadap perasaannya sehingga cenderung memiliki kegemaran untuk melakukan introspeksi atau memperbaiki diri secara terus menerus. Individu yang memiliki kepekaan diri yang tinggi mampu menunjukkan integritas yang tinggi dalam bekerja, menjunjung tinggi nilai-nilai moral, dan menghargai norma-norma yang berlaku di dalam masyarakat.

Riset yang dilaporkan oleh Boyatzis (1999) menunjukkan bahwa aspek dari kompetensi personal, yaitu self-management dan self-regulation terbukti mampu mengangkat produktivitas karyawan sebesar $78 \%$ per tahun (http://eworld-indonesia.com/eworld/). Individu yang seperti ini mampu memaknai dirinya sendiri secara utuh, memahami makna benar dan salah secara konsisten, serta menempatkan dirinya secara proporsional. Secara umum, kompetensi personal ditunjukkan oleh adanya kemampuan sebagai berikut.

1. Mengenali potensi diri. Kemampuan mengenali potensi diri merupakan kecakapan yang dimiliki oleh seseorang untuk memahami kekuatan dan kelemahan yang dimiliki sehingga dapat mengembangkan kemampuan secara optimal dan meminimalisir kelemahan atau bahkan memanfaatkan kelemahan diri sebagai suatu kekuatan.

2. Mengenali emosi diri. Kemampuan mengenali emosi diri adalah kemampuan seseorang dalam mengenali perasaannya sendiri sewaktu perasaan atau emosi itu muncul. Ini sering dikatakan sebagai dasar dari kecerdasan emosional. Seseorang yang mampu mengenali emosinya sendiri adalah apabila ia memiliki kepekaan yang tajam atas perasaan yang sesungguhnya dan kemudian mengambil keputusan secara mantap. Dalam hal ini, misalnya sikap yang diambil dalam menentukan berbagai pilihan, seperti memilih sekolah, sahabat, pekerjaan sampai kepada pemilihan pasangan hidup (Mulyadi, 1999).

3. Mengelola emosi diri. Kemampuan mengelola emosi adalah kemampuan seseorang untuk mengendalikan perasaannya sendiri sehingga tidak 
meledak dan akhirnya dapat mempengaruhi perilakunya secara salah. Ibaratnya adalah seorang pilot pesawat yang dapat membawa pesawatnya ke suatu kota tujuan dan kemudian mendaratkannya secara mulus. Misalnya, seseorang yang sedang marah maka kemarahan itu tetap dapat dikendalikan secara baik tanpa harus menimbulkan akibat yang akhirnya disesalinya di kemudian hari (Mulyadi, 1999). Dalam mengelola emosi diri, ada beberapa hal yang dapat dilakukan, antara lain sebagai berikut.

a. Ketika menghadapi permasalahan dan dituntut untuk segera mengambil keputusan maka seseorang harus berhenti sejenak dan memberikan waktu bagi otak untuk berpikir serta berhati-hati terhadap pesan yang dikirim oleh panca indra karena belum tentu pesan yang melahirkan persepsi itu benar dan bahkan bisa menyesatkan.

b. Sering melakukan observasi kenyataan yang ada di lapangan dan mengajukan pertanyaanpertanyaan reflektif, misalnya mengapa ini bisa terjadi? Apa yang harus saya lakukan untuk keluar dari permasalahan ini? Apa yang masih dapat saya syukuri dari masalah ini? Pertanyaan-pertanyaan ini bergantung dengan konteks masalah yang dihadapi tetapi cara ini sangat efektif untuk membuat ketenangan pertama, istilahnya Pertolongan Pertama Pada Kecemasan (P3K). Pada bagian ini, seseorang sedang mengaktifkan korteks (selaput otak) dari otak. Jadi, biarkan korteks (selaput otak) menganalisis lebih lanjut pesan-pesan yang masuk itu.

c. Menentukan sikap dengan bimbingan suara positif dari dalam korteks (selaput otak).

4. Memotivasi diri

Kemampuan memotivasi diri adalah kemampuan untuk memberikan semangat kepada diri sendiri untuk melakukan sesuatu yang baik dan bermanfaat. Dalam hal ini terkandung adanya unsur harapan dan optimisme yang tinggi sehingga seseorang memiliki kekuatan semangat untuk melakukan suatu aktivitas tertentu. Misalnya, dalam hal belajar, bekerja, dan menolong orang lain (Mulyadi, 1999).

Selanjutnya, secara lebih rinci kompetensi personal bagi PTK-PNF mencakup dimensi sebagai berikut.

1. Self-awareness (Kemampuan untuk mengetahui kondisi internal, preference, resources, dan intuisi).

a. Bertindak sesuai dengan norma-norma agama (spiritual awareness). b. Kemampuan mengendalikan emosi (emotional awareness).

c. Kemampuan untuk mengetahui kekuatan dan keterbatasan (accurate self-assessment).

d. Memiliki keyakinan atau kepercayaan diri (selfconfidence).

2. Self regulation (kemampuan mengelola kondisi internal, impulses, dan resources)

a. Kemampuan pengendalian diri (self-control).

b. Kemampuan untuk memelihara standar kejujuran dan integritas (trustworthiness).

c. Kemampuan mengambil tanggung jawab performa pribadi (conscientiousnesss).

d. Mampu beradaptasi (adaptability).

e. Mampu menciptakan (innovation).

3. Kemampuan untuk mengarahkan emosi pada pencapaian tujuan (motivation).

a. Semangat untuk mencapai yang terbaik (achievement drive).

b. Memiliki komitmen (commitment).

c. Memiliki inisiatif (initiative).

d. Optimis (optimism).

4. Tanggung jawab profesi (professional responsibility).

a. Tanggung jawab profesi.

b. Dedikasi profesi.

c. Pengembangan profesi.

Kemampuan mengelola diri sendiri akan mampu menghindarkan seseorang dari stres, depresi atau bahkan gangguan kejiwaan lebih lanjut. Kompetensi personal memberi bekal bagi seseorang agar memiliki kesehatan psikologis yang baik sehingga dapat menjalankan aktivitasnya secara normal. Bagi PTKPNF yang memiliki beban kerja cukup berat dan kompleks memerlukan kompetensi personal yang sangat baik sehingga dapat mencapai prestasi optimal.

Dimensi-dimensi kompetensi personal di atas dapat dikuasai oleh seseorang melalui latihan yang bersifat intensif. Pelatihan yang dimaksud mencakup:

1. latihan melakukan instropeksi diri dengan mengembangkan dialog pada diri sendiri. Introspeksi ini akan memberikan pemahaman yang mendalam mengenai diri sendiri, di samping menyadari kekurangan dan kelebihan yang ada;

2. latihan untuk mengelola emosi diri, meletakkan diri secara proporsional dalam hubungan sosial dan bertanggung jawab atas tindakan yang dilakukan; serta

3. latihan memotivasi diri (inner motivation) secara intensif karena bagaimanapun motivasi diri merupakan kekuatan internal yang sangat besar.

Latihan ini apabila dilakukan secara terus menerus akan membentuk pribadi paripurna yang dapat 
mengendalikan dan mengarahkan diri pada tujuan yang positif.

\section{Kompetensi Sosial bagi PTK-PNF}

Dalam kaitannya dengan kompetensi sosial, seseorang yang memahami kondisi lingkungan termasuk di dalamnya pemahaman terhadap orang lain (empati), memahami adanya perbedaan (diversity) dapat memanfaatkannya untuk menyikapi kondisi-kondisi yang ada dalam lingkungannya. Untuk kompetensi sosial ini Boyatzis (2006) telah melaporkan adanya kenaikan kinerja karyawan yang memiliki kompetensi sosial yang tinggi sebesar 110\% (http://eworldindonesia.com/eworld/). Dengan demikian, kompetensi sosial lebih merujuk pada aspek-aspek sosial yang mutlak harus dimiliki oleh seseorang untuk menghasilkan kinerja yang istimewa.

Kompetensi sosial merupakan kecakapan seseorang dalam berinteraksi dengan orang lain dan menunjukkan kemampuannya dalam memahami perasaan orang lain sehingga mudah dalam bersosialisasi. Individu yang memiliki kompetensi sosial tinggi mampu menjalin hubungan yang akrab dengan orang lain, termasuk di dalamnya kemampuan seperti memimpin, mengorganisasi, menangani perselisihan, dan memperoleh simpati dari orang lain. Kompetensi sosial mencakup sebagai berikut.

1. Kemampuan untuk membina hubungan. Kemampuan membina hubungan adalah kemampuan untuk mengelola emosi orang lain sehingga tercipta keterampilan sosial yang tinggi dan membuat pergaulan seseorang menjadi lebih luas. Individu dengan kemampuan ini cenderung mempunyai banyak teman, pandai bergaul, dan menjadi lebih populer (Mulyadi, 1999).

2. Kemampuan untuk mengenali emosi orang lain. Kemampuan mengenali emosi orang lain adalah kemampuan untuk mengerti perasaan dan kebutuhan orang lain sehingga orang lain akan merasa senang dan dimengerti perasaannya. Anakanak yang memiliki kemampuan ini, yaitu sering pula disebut sebagai kemampuan berempati dan mampu menangkap pesan nonverbal orang lain, seperti nada bicara, gerak-gerik maupun ekspresi wajah dari orang lain tersebut (Mulyadi, 1999). Dengan demikian, individu seperti ini akan cenderung disukai orang.

3. Kemampuan untuk berpikir dan bersikap terbuka. Ini merupakan kecakapan yang dimiliki oleh seseorang untuk memahami kondisi yang terjadi di sekelilingnya dengan cara-cara yang wajar. Termasuk di dalamnya kemampuan untuk berpikir adalah sebagai berikut. a. Mempersepsi sesuatu kejadian, peristiwa atau fenomena dengan baik.

b. Mengolah pengalaman bersama orang lain menjadi sesuatu yang berharga.

c. Memberikan pujian dan dukungan kepada orang lain.

d. Menerima orang lain sebagaimana adanya sehingga tidak memaksakan kehendak dan pikiran seseorang kepada orang lain.

Adapun berpikir terbuka adalah sebagai berikut.

a. Berpikir terbuka tentang diri sendiri.

b. Berpikir terbuka tentang orang tua.

c. Berpikir terbuka tentang orang-orang terdekat.

d. Berpikir terbuka tentang masa kini.

e. Berpikir terbuka tentang masa lalu.

f. Berpikir terbuka tentang masa depan.

g. Berpikir terbuka tentang hidup. Secara rinci kompetensi sosial bagi PTK-PNF mencakup berbagai dimensi adalah sebagai berikut.

1. Peduli terhadap perasaan dan kebutuhan orang lain (Emphaty).

a. Memahami orang lain (understanding others).

b. Mengembangkan orang lain (developing others).

c. Orientasi pelayanan (service orientation).

d. Menumbuhkan aneka peluang dengan aneka ragam manusia (leveraging diversity).

e. Membaca emosi kelompok pada saat ini dan kekuatan hubungan (political awareness).

2. Kecakapan sosial (social skills).

a. Pengaruh (influence).

b. Komunikasi (communication).

c. Mengelola konflik (conflict management).

d. Kepemimpinan (leadership).

e. Mengiinisiasi atau mengelola perubahan (change catalyst).

f. Membangun ikatan (building bond).

g. Kolaborasi dan kooperasi (collaboration and cooperation).

h. Menciptakan sinergi kelompok dalam meraih tujuan bersama (team capabilities).

i. Tanggung jawab sosial (social responsibility).

j. Memahami budaya untuk mencapai tujuan bersama (cultural understanding).

Humphreys (2003) menyebutkan bahwa dalam membangun hubungan dengan orang lain ada dua jenis hubungan yang perlu diperhatikan, yaitu hubungan yang memang harus dihindari karena jenis hubungan ini tidak sehat dan hubungan yang harus dibangun terus karena dapat memberikan keamanan dan kenyamanan. Kedua jenis hubungan ini memiliki ciri-ciri sebagai berikut. 
Tabel 1. Ciri-ciri Hubungan yang Harus Dihindari

\begin{tabular}{|ll|ll|}
\hline \multicolumn{3}{|c|}{ Ciri-ciri hubungan yang harus dihindari } \\
\hline o & Pasif & 0 & Agresi \\
o & Posesif & 0 & Celaan \\
o & Kebencian & 0 & Kekerasan \\
0 & Kurangnya cinta & 0 & Tidak menghormati \\
o & Sikap menghukum & 0 & Sikap mendominasi \\
o & Sikap menyalahkan & 0 & Sikap mengabaikan \\
o & Sikap memanipulasi & 0 & Tidak ada tantangan \\
0 & Sikap mengendalikan & 0 & Penuh syarat (tidak tulus) \\
\hline
\end{tabular}

Tabel 2. Ciri-ciri Hubungan yang Harus Dikembangkan

\begin{tabular}{|ll|ll|}
\hline \multicolumn{3}{|c|}{ Ciri-ciri hubungan yang harus dikembangkan } \\
\hline o & Adil & 0 & Jujur \\
o & Tulus & 0 & Tegas \\
o & Sabar & 0 & Dewasa \\
o & Terbuka & 0 & Afirmasi \\
o & Toleransi & 0 & Menerima \\
o & Lemah lembut & 0 & Sikap memahami \\
o & Sikap menyayangi & 0 & Sikap menghormati \\
o & Sikap menghargai & 0 & Sikap mempercayai \\
o & Aktif mendengarkan & 0 & Kelembutan yang positif \\
o & Yakin pada diri sendiri & 0 & Semangat dalam berusaha \\
o & Menghargai setiap usaha & 0 & Tegar dalam menghadapi masalah \\
o & Penuh tanggung jawab & & \\
\hline
\end{tabular}

Individu yang dapat mengembangkan kompetensi sosial ini akan memiliki hubungan yang harmonis dan kehadirannya akan menjadi bagian dari pemecahan masalah (problem solving). Kompetensi sosial akan mengarahkan individu pada komitmen yang tinggi untuk menjalankan tanggung jawab sosial dan moral pada tingkat komunitas. Apabila banyak individu atau bahkan PTK-PNF yang memiliki kompetensi sosial dalam tingkatan baik diharapkan tumbuh kohesif yang tinggi sehingga permasalahan yang bersifat sosial atau kolektif dapat teratasi dengan mudah.

\section{Kompetensi Personal dan Sosial dan Peningkatan Prestasi PTK-PNF}

PTK-PNF yang memiliki kompetensi personal dan sosial pada tingkatan baik akan mengantarkannya pada kesuksesan dan prestasi tinggi, meskipun rintangan dan permasalahan di lapangan sangat kompleks. Kompetensi personal dan sosial mampu mencetak individu yang memiliki karakter kuat dan baik sehingga dapat menjalani kehidupannya dengan sukses.

Ciri-ciri PTK-PNF yang memiliki kompetensi personal dan sosial baik adalah sebagai berikut.

1. Memiliki integritas moral dan religiositas yang tinggi sehingga dalam setiap tindakannya mendasarkan pada nilai luhur dan norma yang berlaku baik norma agama maupun kemasyarakatan. Dengan demikian, PTK-PNF akan memiliki budi pekerti yang luhur sehingga dapat menjadi panutan masyarakat.

2. Memiliki kepribadian yang mantap sehingga memiliki kemantapan dalam melaksanakan tugas, tanggung jawab, dan mengambil keputusan yang terbaik dengan segala resiko atau konsekuensinya.

3. Merasa nyaman tehadap dirinya. Individu yang merasa nyaman terhadap dirinya berarti mampu menghadapi berbagai perasaan, seperti:

a. mampu mengatasi kekecewaan dalam kehidupan; 
b. mempunyai harga diri yang wajar;

c. menilai dirinya secara nyata, tidak merendahkan dan tidak pula berlebihan; dan

d. merasa puas dengan kehidupan sehari-hari;

2. Merasa nyaman berhubungan dan menerima cinta dari orang lain.

a. Mampu mencintai dan menerima cinta dari orang lain.

b. Mempunyai hubungan pribadi yang tetap.

c. Mampu mempercayai orang lain.

d. Dapat menghargai pendapat orang lain yang berbeda.

e. Merasa menjadi bagian dari kelompok.

f. Tidak mengakali orang lain dan tidak membiarkan dirinya diakali oleh orang lain.

3. Mampu memenuhi kebutuhan hidup.

a. Menetapkan tujuan hidup yang nyata untuk dirinya.

b. Mampu mengambil keputusan.

c. Menerima tanggung jawab.

d. Merancang masa depan.

e. Menerima ide dan pengalaman baru.

f. Merasa puas dengan pekerjaannya.

Dengan demikian, PTK-PNF yang memiliki karakter sebagaimana di atas akan dapat melakukan berbagai tindakan positif adalah sebagai berikut.

1. Dapat menyesuaikan diri secara konstruktif pada kenyataan meskipun kenyataan itu buruk baginya.

2. Memperoleh kepuasan dari hasil jerih payah usahanya.

3. Merasa lebih puas memberi daripada menerima.

4. Secara relatif bebas dari rasa tegang dan cemas.

5. Berhubungan dengan orang lain secara tolongmenolong dan saling memuaskan.

6. Menerima kekecewaan untuk dipakainya sebagai pelajaran di kemudian hari.

7. Menjuruskan rasa permusuhan kepada penyelesaian yang kreatif dan konstruktif.

8. Mempunyai rasa kasih sayang yang besar.

9. Kriteria tersebut disempurnakan dengan menambahkan satu elemen spiritual (agama) sehingga kesehatan mental ini bukan sehat dari segi fisik, psikologis, dan sosial saja melainkan sehat dalam arti spiritual.
Untuk mencetak PTK-PNF yang memiliki karakter kepribadian di atas beberapa prinsip yang harus dikembangkan adalah sebagai berikut.

1. Gambaran dan sikap yang baik terhadap diri sendiri (self-image). Prinsip ini dapat dicapai dengan penerimaan diri, keyakinan atau kepercayaan pada diri sendiri. Citra diri positif akan mewarnai pola hidup, sikap, cara pikir, dan corak penghayatan, serta ragam perbuatan yang positif pula.

2. Keterpaduan antara integrasi diri. Adanya keseimbangan antara kekuatan-kekuatan jiwa dalam diri, kesatuan pandangan (falsafah) dalam hidup, dan kesanggupan mengatasi stres (Sururin, 2004:146).

3. Perwujudan diri (aktualisasi diri), inilah proses pematangan diri. Menurut Reiff (1990) Orang yang sehat mentalnya adalah orang yang mampu mengaktualisasikan diri atau mampu mewujudkan potensi yang dimilikinya, serta memenuhi kebutuhan-kebutuhannya dengan cara yang baik dan memuaskan.

4. Mau menerima orang lain, mampu melakukan aktivitas sosial, dan menyesuaikan diri dengan lingkungan tempat tinggal.

5. Berminat dalam tugas dan pekerjaan. Pribadi yang mengembangkan prinsip ini sangat menyukai tantangan dan mengerjakan pekerjaan rumit yang bagi orang lain tampaknya tidak mungkin. Pribadi ini akan selalu bekerja keras, ulet, dan tangguh sehingga dapat mencapai tujuan.

6. Agama, cita-cita, dan falsafah hidup demi menggapai ketenangan dan kebahagiaan dalam kehidupan.

7. Pengawasan diri. Hal ini dapat dilakukan terhadap keinginan-keinginan dari ego yang bersifat biologis murni sehingga dapat dikendalikan secara sehat dan terarah.

8. Rasa benar dan tanggung jawab, ini penting bagi tingkah laku. Dengan demikian, muncul rasa percaya diri dan bertanggung jawab penuh atas segala tindakan sehingga tidak menutup kemungkinan kesuksesan diri akan diraih.

\section{KESIMPULAN}

PTK-PNF memiliki kompetensi personal dan sosial yang baik berarti mampu beradaptasi dalam segala kondisi lingkungan sehingga tidak mudah menyerah dan mampu membina hubungan dengan pihak lain dalam cara-cara yang wajar tetapi mengesankan. Berdasarkan kemampuan ini akan 
mengantarkan PTK-PNF pada tingkat kesuksesan bekerja. Integritas, komitmen, dan citra diri menjadi kata kunci bagi peningkatan kompetensi personal dan sosial PTK-PNF menjadi pribadi yang unggul dan tangguh.

\section{DAFTAR PUSTAKA}

Boyatzis. (1999). Human stress. (http://eworldindonesia.com/eworld/, diakses pada tanggal 23/04/08).

Boyatzis. (2006). Emotional competence.(http://eworldindonesia.com/eworld/, diakses pada tanggal 23/04/08).

Humphreys, T. (2003). Bangkitkan kekuatan dalam pribadi anda. Bandung: Nuansa.

Mc. Clelland. (1953). Testing for competence rather than intelligence. USA: Prentice-Hall.
Mulyadi, S. (1999). Mempersiapkan anak unggul milenium III. (http://www.mail-archive.com/ balita-anda@indoglobal.com/msg07186.html, diakses tanggal pada 23/04/08).

Reiff. (1990). Individual performance. Boston: Kent Publishing Company.

Spencer \& Spencer. (1956). Hay/McBer's generic competency dictionary. USA: Prentice-Hall.

Sururin. (2004). Kinerja dan karyawan. Yogyakarta: Pustaka Utama. 